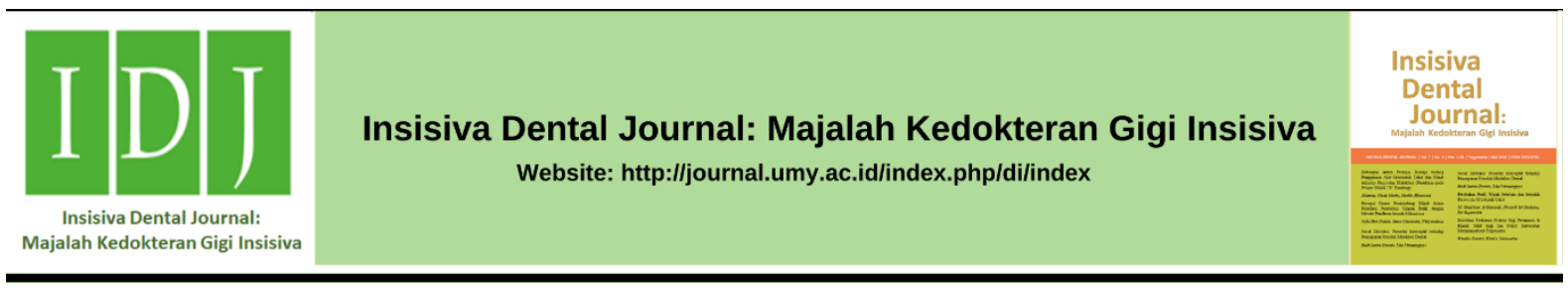

Research Article

\title{
Hubungan Kesiapan dan Gaya Belajar dengan Tingkat Kelulusan Ujian Multiple Choice Question (MCQ)
}

The Correlation between Self-Directed Learning Readiness and Style with Multiple Choice Question (MCQ) Pass Rate

Indri Kurniasih" ${ }^{1, *}$, Dinni Alifa Azzahra ${ }^{2}$

${ }^{1}$ Unit Pengembangan Pendidikan Kedokteran Gigi, Program Studi Kedokteran Gigi, Fakultas Kedokteran dan Ilmu Kesehatan, Universitas Muhammadiyah Yogyakarta, Jalan Brawijaya, Geblagan, Tamantirto, Kasihan, Bantul, Indonesia

${ }^{2}$ Program Studi Kedokteran Gigi, Fakultas Kedokteran dan Ilmu Kesehatan, Universitas Muhammadiyah Yogyakarta, Jalan Brawijaya, Geblagan, Tamantirto, Kasihan, Bantul, Indonesia

Received date: September $29^{\text {th }}, 2019$; reviewed date: July $11^{\text {th }}, 2020$ revised date: August $7^{\text {th }}, 2020$; accepted date: August $25^{\text {th }}$, 2020 DOI : $10.18196 /$ di. 9218

\begin{abstract}
Abstrak
Masa transisi terjadi pada mahasiswa baru yang mengalami proses adaptasi dengan lingkungan kampusnya. Selama penyesuaian diri mahasiswa terkadang mengalami masalah psikologis dengan perubahan metode belajar, karena mahasiswa masih cenderung menerapkan cara belajar ketika belajar di sekolah menengah atas. Setiap mahasiswa memiliki kesiapan belajar (Self Directed Learning Readiness/SDLRS) dan gaya belajar (learning styles) yang dapat mempengaruhi hasil belajar. Multiple Choice Questions (MCQ) merupakan salah satu penilaian hasil belajar dengan tingkat objektivitas tinggi. Tujuan penelitian ini untuk mengetahui hubungan kesiapan belajar dan gaya belajar mahasiswa dengan tingkat kelulusan ujian MCQ. Metode penelitian adalah deskriptif analitik dengan desain cross sectional. Jumlah responden penelitian sebanyak 82 mahasiswa dipilih secara stratified random sampling. Kuesioner SDLRS dan Visual, Auditory, Read-White, Kinaesthetic (VARK) digunakan untuk mendapatkan data primer tentang kesiapan belajar dan gaya belajar mahasiswa. Data Sekunder yang digunakan adalah jumlah kelulusan ujian MCQ pada blok 1 sampai 6. Analisis uji Somers'd menunjukkan nilai $\mathrm{p}=0,237$ ( $p>0,05)$, yang berarti tidak terdapat hubungan yang signifikan antara kesiapan belajar dengan tingkat kelulusan ujian MCQ. Hasil analisis uji Lambda menunjukkan nilai p =0,178 (p>0,05), yang berarti tidak terdapat hubungan yang signifikan antara gaya belajar dengan tingkat kelulusan ujian MCQ. Gaya belajar mahasiswa didominasi oleh gaya belajar kinestetik. Berdasarkan hasil penelitian ini dapat disimpulkan bahwa kesiapan belajar dan gaya belajar mahasiswa tidak berhubungan dengan tingkat kelulusan ujian MCQ.
\end{abstract}

Kata Kunci: Learning style; Multiple Choice Question (MCQ); Self-Directed learning readiness (SDLR)

\begin{abstract}
The transition period occurs for new students who experience a process of adaptation to the campus environment. During the adaptation period, students sometimes experience psychological problems with changes in learning methods as they still tend to apply their previous learning methods in high schools. Each student has Self-Directed Learning Readiness (SDLR) and learning style, affecting their learning outcomes. Meanwhile, Multiple Choice Questions (MCQ) assesses learning outcomes with a high level of objectivity. This study aimed to identify the relationship between students' learning readiness and learning styles with the passing rate of the Multiple-Choice Question (MCQ) exam. This research applied a descriptive-analytic method with a cross-sectional design. The number of research respondents was 82 students selected by stratified random sampling. Self-Directed Learning Readiness Scales (SDLRS) and VARK (Visual, Auditory, Read-Write, Kinesthetic) questionnaires were utilized to obtain primary data about students' learning readiness and learning styles. Secondary data used were the passing rate in the Multiple-Choice Questions (MCQ) examination in Blocks 1 to 6. Somers'd test analysis showed a pvalue of $=0.237(p>0.05)$, indicating no significant relationship between learning readiness and the passing rate
\end{abstract}

\footnotetext{
* Corresponding author, e-mail: indri.kurniasih@umy.ac.id
} 
of MCQ. Besides, the Lambda test analysis results revealed a $p$-value $=0.178$ ( $p>0.05)$, signifying that there was no significant relationship between learning styles and the passing rate of MCQ. Students' learning styles were dominated by kinesthetic learning styles. Based on this study's results, it could be concluded that students' learning readiness and learning styles were not correlated with the passing rate of the MCQ exam in the firstyear block at the Dentistry Education Study Program of UMY.

Keywords: Learning style; Multiple Choice Question (MCQ); Self-Directed learning readiness (SDLR)

\section{PENDAHULUAN}

Masa transisi pada perkuliahan tahun pertama merupakan masa mahasiswa menyesuaikan perubahan metode pembelajaran dan lingkungan belajar dari sekolah menengah atas ke lingkungan perguruan tinggi. Perilaku belajar mahasiswa baru masih menerapkan dan menunjukkan cara belajar ketika berada di sekolah menengah atas. Masih terdapat banyak mahasiswa baru yang belum memiliki kesiapan belajar mandiri, sehingga belajar mahasiswa kurang optimal dalam mencapai prestasi akademik. ${ }^{1}$

Mahasiswa kedokteran pada tahun pertama akan mengalami kesulitan karena silabus yang luas dengan periode waktu yang singkat. Usia, pengalaman, latar belakang budaya, tingkat kesiapan belajar dan gaya belajar dapat berpengaruh pada hasil pencapaian belajar mahasiswa. ${ }^{2}$ Institusi pendidikan kedokteran memiliki peran penting dalam mengembangkan kesiapan belajar mandiri mahasiswa, yang memerlukan suatu penilaian kesiapan belajar terhadap hasil belajar mahasiswa. ${ }^{3}$

Faktor internal yang mempengaruhi hasil belajar diantaranya terdiri dari faktor psikologis dan fisik. Faktor psikologis meliputi kemampuan intelektual, perhatian, minat, bakat, motivasi, kesiapan dan kedewasaan. Individu memerlukan kesiapan belajar untuk mencapai tujuan belajar. $^{4}$ Peserta didik yang mengeluhkan tidak siap menghadapi lingkungan belajar, diantaranya kurangnya inisiatif, tanggung jawab, dan pemahaman dalam interpretasi mengenai belajar mandiri (Self Directed Learning). Belajar mandiri yang dilatihkan pada peserta didik dapat mendorong terbentuknya tanggung jawab dalam proses belajar. Belajar merupakan salah satu bentuk kesiapan belajar yang dapat menjadi kriteria keberhasilan pembelajaran Problem Based Learning, dalam menyiapkan mahasiswa sebagai long life learner. ${ }^{5}$ Faktor internal lain yang berpengaruh pada hasil belajar adalah gaya belajar. Setiap individu mempunyai gaya belajar yang unik dalam menerima, mengolah dan mengatur informasi yang diterima. ${ }^{6}$ Terdapat empat jenis gaya belajar (learning styles) yaitu visual, auditory, read-write dan kinestetik. ${ }^{7}$

Hasil belajar dapat dinilai melalui suatu ujian yang dilakukan selama ataupun di akhir pembelajaran. Salah satu bentuk ujian blok di Program Studi Kedokteran Gigi, Fakultas kedokteran dan Ilmu Kesehatan, Universitas Muhammadiyah Yogyakarta (PSKG FKIK UMY) adalah Multiple Choice Questions (MCQ). Ujian MCQ merupakan suatu penilaian yang dapat digunakan untuk menguji wawasan mahasiswa mengenai beberapa topik dalam waktu singkat dengan cara yang efisien karena mencakup konten yang luas. MCQ mempunyai tingkat objektivitas tinggi serta mudah dalam analisis dan pelaporan hasilnya. ${ }^{8}$

Penelitian ini bertujuan untuk mengetahui hubungan Self Directed Learning Readiness (SDLR) terhadap hasil ujian MCQ dan hubungan gaya belajar (learning styles) dalam proses belajar dengan hasil ujian MCQ yang diperoleh mahasiswa di tahun pertama.

\section{MATERIAL DAN METODE}

Jenis penelitian yang dilakukan merupakan penelitian observasional analitik dengan desain penelitian cross sectional. Penelitian dilaksanakan di PSKG 
FKIK UMY pada bulan April 2018. Subjek penelitian adalah mahasiswa PSKG tahun ke-1 sampai dengan ke-3 dan dipilih dengan teknik Proportional Random Sampling. Kriteria inklusi penelitian ini adalah mahasiswa aktif yang telah mengikuti ujian pada blok tahun pertama dan bersedia menjadi subjek penelitian. Kriteria eksklusi adalah mahasiswa yang sedang dalam gangguan kondisi fisik, tidak atau belum mengikuti ujian blok dan tidak mengisi kuisioner dengan benar. Jumlah sampel untuk setiap kelompok menggunakan cara proporsional.

Kuesioner SDLRS digunakan dalam penelitian ini untuk mengukur kesiapan peserta didik melakukan pembelajaran mandiri. Kuesioner SDLRS memuat tiga komponen kesiapan belajar adalah pengaturan diri, keinginan untuk belajar dan kontrol diri. Tiga puluh delapan item dinyatakan valid $(\mathrm{r}>0,312)$ dan reliabel $(\alpha=0.916)$ dari 48 item kuesioner SDLRS yang diubah dalam bahasa Indonesia. Untuk mengetahui karakteristik gaya belajar mahasiswa diukur menggunakan kuesioner VARK (Visual, Auditory, Read-Write, Kinesthetic). Data sekunder nilai MCQ pada Blok 1 - 6 digunakan untuk menentukan tingkat kelulusan ujian MCQ mahasiswa di tahun pertama.

Uji korelasi Somers'd digunakan untuk menganalisis hubungan SDLR dengan hasil ujian MCQ, karena variabel yang diuji merupakan variabel skala ordinal tidak setara. Untuk menganalisis hubungan gaya belajar (learning styles) dengan hasil ujian MCQ digunakan uji korelasi Lambda, karena variabel data nominal dengan ordinal. ${ }^{9}$

\section{HASIL}

Jumlah responden yang terlibat dalam penelitian ini sebanyak 84 mahasiswa dengan distribusi 28 mahasiswa dari angkatan mahasiswa 2014, 30 mahasiswa angkatan 2015 dan 26 mahasiswa angkatan 2016. Terdapat 2 mahasiswa yang tidak memenuhi kriteria inklusi sehingga data tersebut dikeluarkan dari analisis hasil. Adapun analisis data yang dilakukan adalah sebagai berikut:

\section{Uji Univariat}

Subjek yang memenuhi kriteria inklusi penelitian berjumlah 82 (tabel 1).

Tabel 1. Subjek berdasarkan jenis kelamin

\begin{tabular}{ccccc}
\hline Responden & Valid & Gugur & Jumlah & Persentase (\%) \\
\hline Laki-laki & 18 & 1 & 17 & 20.7 \\
Perempuan & 66 & 1 & 65 & 79.3 \\
Jumlah & 84 & 2 & 82 & 100.0 \\
\hline
\end{tabular}

Data sekunder tingkat kelulusan MCQ didapat dengan mengelompokkan nilai MCQ blok pada beberapa kategori, diawali dengan menganalisa data jumlah kelulusan MCQ blok dari 82 mahasiswa pada tahun pertama (tabel 2).

Tabel 2. Distribusi frekuensi kelulusan Multiple Choice Questions (MCQ)

\begin{tabular}{ccc}
\hline $\begin{array}{c}\text { Jumlah Kelulusan } \\
\text { Blok }\end{array}$ & Frekuensi & Persentase (\%) \\
\hline 0 & 4 & 4.9 \\
1 & 11 & 13.4 \\
2 & 11 & 13.4 \\
3 & 16 & 19.5 \\
4 & 18 & 22.0 \\
5 & 14 & 17.1 \\
6 & 8 & 9.8 \\
& 82 & 100.0 \\
\hline
\end{tabular}


Indikator hasil belajar MCQ dikelompokkan dengan menghitung persentase menurut Arikunto (2008). Kategori tingkat kelulusan tinggi sekali (81-100\%), tinggi (61-80\%), sedang (40-60\%), rendah (21-40\%) dan sangat rendah (0-20\%). Analisa deskriptif menunjukkan 48,8 $\%$ mahasiswa PSKG UMY termasuk dalam kategori tinggi dan tinggi sekali untuk kategori kelulusan MCQ pada blok di tahun pertama (tabel 3).

Tabel 3. Distribusi frekuensi tingkat kelulusan MCQ blok tahun pertama mahasiswa PSKG UMY

\begin{tabular}{llcc}
\hline \multicolumn{1}{c}{ Jumlah Lulus } & \multicolumn{1}{c}{ Kategori } & Frekuensi & Persentase (\%) \\
\hline Lulus 0-1 & Rendah Sekali & 15 & 18.3 \\
Lulus 2 & Rendah & 11 & 13.4 \\
Lulus 3 & Sedang & 16 & 19.5 \\
Lulus 4 & Tinggi & 18 & 22.0 \\
Lulus 5-6 & Tinggi Sekali & 22 & 26.8 \\
& Total & 82 & 100.0 \\
\hline
\end{tabular}

Hasil analisis data menunjukkan mahasiswa PSKG UMY memiliki kesiapan belajar sedang dan tinggi (tabel 4).

Tabel 4. Distribusi frekuensi SDLR mahasiswa PSKG UMY

\begin{tabular}{ccc}
\hline & Frekuensi & Persentase $(\%)$ \\
\hline Rendah & 0 & 0 \\
Sedang & 10 & 12.2 \\
Tinggi & 72 & 87.8 \\
Total & 82 & 100.0 \\
\hline
\end{tabular}

Hasil analisis data kuesioner VARK menunjukkan bahwa mahasiswa PSKG UMY cenderung memiliki gaya belajar unimodal $(86,6 \%)$. Bentuk gaya belajar terbanyak adalah kinestetik $(34,1 \%)$ sebagaimana diuraikan pada tabel 5.

Tabel 5. Distribusi frekuensi tipe gaya belajar mahasiswa PSKG UMY

\begin{tabular}{lcc}
\hline & Frekuensi & Persentase (\%) \\
\hline Auditori & 17 & 20.7 \\
Kinestetik & 28 & 34.1 \\
Kinestetik-Auditori & 5 & 6.1 \\
Kinestetik-Read-Write & 2 & 2.4 \\
Read-Write & 18 & 22.0 \\
VARK & 1 & 1.2 \\
Visual & 8 & 9.8 \\
Visual-Read-Write & 3 & 3.7 \\
Total & 82 & 100.0 \\
\hline
\end{tabular}

\section{Analisis Bivariat}

Data yang diperoleh dari kuesioner SDLRS yang telah terkategori ditabulasi secara silang dengan tingkat kelulusan MCQ (tabel 6). 
Tabel 6. Tabulasi silang SDLR - tingkat kelulusan MCQ

\begin{tabular}{lcccccc}
\hline \multicolumn{7}{c}{ Tingkat Kelulusan MCQ } \\
\hline SDLR & Rendah sekali & Rendah & Sedang & Tinggi & Tinggi Sekali & Total \\
\hline Rendah & 0 & 0 & 0 & 0 & 0 & 0 \\
Sedang & 3 & 2 & 2 & 1 & 2 & 10 \\
Tinggi & 12 & 9 & 14 & 17 & 20 & 72 \\
Total & 15 & 11 & 16 & 18 & 22 & 82 \\
\hline
\end{tabular}

Analisa uji korelasi menggunakan uji Somers'd Self Directed Learning karena kedua jenis data adalah ordinal. Hasil analisis tersaji dalam tabel 7.

Tabel 7. Hasil uji korelasi Somers'd antara SDLR dengan tingkat kelulusan MCQ

\begin{tabular}{llr}
\hline \multicolumn{3}{c}{ Kelulusan MCQ } \\
\hline SDLR & Value (r) & 0,064 \\
& Sig (p) & 0,237 \\
& $\mathrm{~N} \quad$ & 82 \\
\hline
\end{tabular}

Hasil uji korelasi menunjukkan value (r) 0,064 yang berarti hubungan korelasi sangat lemah. Hasil signifikansi (p) 0,237 menunjukkan tidak terdapat hubungan yang signifikan antara gaya belajar dan hasil ujian MCQ blok tahun pertama.

Hasil kategori gaya belajar (learning styles) yang diperoleh dari VARK Questionnare dikelompokkan secara tabulasi silang dengan tingkat kelulusan MCQ tersaji dalam tabel 8 . Berikut.

Tabel 8. Analisa Gaya belajar-tingkat kelulusan MCQ

\begin{tabular}{ccccccc}
\hline & \multicolumn{7}{c}{ Tingkat Kelulusan MCQ } \\
\hline Gaya Belajar & Rendah & Rendah & Sedang & Tinggi & Tinggi Sekali & Total \\
& Sekali $(\%)$ & $(\%)$ & $(\%)$ & $(\%)$ & $(\%)$ & $(\%)$ \\
\hline Auditory & $3(3.7)$ & $2(2.4)$ & $3(3.7)$ & $5(6.1)$ & $4(4.9)$ & $17(20.7)$ \\
Kinestetik & $9(11.0)$ & $4(4.9)$ & $4(4.9)$ & $6(7.3)$ & $5(6.1)$ & $28(34.1)$ \\
Kinestetik-Auditory & $0(0)$ & $0(0)$ & $2(2.4)$ & $1(1.2)$ & $2(2.4)$ & $5(6.1)$ \\
Kinestetik-Read- & $0(0)$ & $0(0)$ & $0(0)$ & $1(1,2)$ & $1(1,2)$ & $2(2.4)$ \\
write & $0(0)$ & $2(2.4)$ & $5(6.1)$ & $3(3.7)$ & $8(9.8)$ & $18(22.0)$ \\
Read-write & $0(0)$ & $1(1.2)$ & $0(0)$ & $0(0)$ & $0(0)$ & $1(1.2)$ \\
VARK & $3(3.7)$ & $1(1.2)$ & $2(2.4)$ & $1(1.2)$ & $1(1.2)$ & $8(9.8)$ \\
Visual & $0(0)$ & $1(1.2)$ & $0(0)$ & $1(1.2)$ & $1(1.2)$ & $3(3.7)$ \\
Visual-Read-write & $15(18.3)$ & $11(13.4)$ & $16(19.5)$ & $18(22.0)$ & $22(26.8)$ & $82(100.0)$ \\
Total & & & & & &
\end{tabular}

Berdasarkan tabel 8, gaya belajar merupakan jenis data nominal dan tingkat kelulusan MCQ merupakan jenis data ordinal, sehingga analisis uji korelasi yang digunakan adalah Lambda, sebagai berikut:

Tabel 9. Hasil uji korelasi Lambda antara gaya belajar dengan tingkat kelulusan MCQ

\begin{tabular}{llc}
\hline & Tingkat Kelulusan MCQ \\
\hline Gaya belajar & Value $(\mathrm{r})$ & 0,074 \\
& Sig $(\mathrm{p})$ & 0,392 \\
$\mathrm{~N}$ & 82
\end{tabular}


Hasil uji korelasi menunjukkan value (r) yang diperoleh sebesar 0,074 yang berarti bahwa terdapat hubungan korelasi sangat lemah. Hasil signifikansi sebesar 0,392 yang menunjukkan tidak terdapat hubungan yang signifikan antara gaya belajar (learning styles) dengan hasil ujian MCQ.

\section{PEMBAHASAN}

SDLR merupakan kesiapan atau kesediaan individu untuk belajar mandiri terdiri dari komponen sikap, kemampuan dan karakteristik kepribadian. ${ }^{10}$ Aspek psikologis yang dapat mempengaruhi hasil belajar salah satunya adalah aspek kesiapan. Kesiapan diperlukan individu dalam proses belajar untuk hasil belajar yang lebih baik. Kesiapan dapat dipengaruhi beberapa aspek diantaranya kondisi fisik, emosional, faktor kebutuhan, motivasi, tujuan, keterampilan, pengetahuan dan hal lain yang telah dipelajari. Kebutuhan berhubungan dengan kesiapan, karena individu yang menyadari kebutuhan akan mendorong usahanya untuk berbuat sesuatu. Kesiapan belajar ditentukan oleh kebutuhan dan faktor psikologis yang dapat mempengaruhi hasil belajar. Faktor internal lain yang dapat mempengaruhi hasil belajar adalah faktor jasmani dan kelelahan. ${ }^{4}$

Hasil penelitian ini menunjukkan bahwa, $87,8 \%$ mahasiswa kedokteran gigi FKIK UMY memiliki kesiapan belajar yang tinggi, namun tidak ditemukan hubungan yang signifikan antara SDLR dengan tingkat kelulusan ujian MCQ Blok di tahun pertama (tabel 7). Tingkat kesiapan belajar yang berbeda dapat dipengaruhi oleh aspek perhatian selama mengikuti kegiatan belajar yang dapat dilihat dari konsentrasi peserta didik, aspek motivasi ketepatan waktu dalam proses belajar, dan kemampuan peserta didik dalam menyimpulkan materi yang telah didapatkan. ${ }^{11}$ Pada penelitian sebelumnya didapat bahwa SDLR tidak berhubungan dengan kelulusan ujian tulis blok semester pertama, walaupun skor yang diperoleh mahasiswa berada pada kategori tinggi dan hampir sebagian besar mahasiswa lulus ujian tulis blok semester pertama. ${ }^{12}$

Hasil penelitian juga menunjukkan tidak terdapat hubungan antara gaya belajar (learning styles) dengan tingkat kelulusan ujian MCQ Blok di tahun pertama. Gaya belajar merupakan kombinasi yang dilakukan oleh individu dalam menyerap, mengatur dan mengolah informasi belajar. ${ }^{13}$ Sikap individu dalam mengolah materi belajar, mengingat hasil belajar, kebiasaan dan kemampuan berprestasi merupakan faktor internal dalam proses belajar. ${ }^{14}$ Faktor yang dapat menyebabkan tidak adanya hubungan antara gaya belajar (learning styles) dengan hasil belajar adalah kurangnya kemampuan mahasiswa dalam menyadari gaya belajar yang dimilikinya, gaya belajar yang tidak sesuai dengan strategi pembelajaran, lebih konsentrasi pada penguasaan bahan ajar, dan desain kelas yang kurang kondusif. Hasil belajar yang baik dapat diperoleh mahasiswa dengan menyadari gaya belajar dan dapat menerapkan gaya belajar yang optimal selama proses belajar. ${ }^{15}$ Dari penelitian ini diketahui bahwa mahasiswa PSKG UMY memiliki gaya belajar unimodal sebesar $86,5 \%$ dan multimodal sebesar $13,4 \%$. Gaya belajar unimodal yang mendominasi adalah kinestetik $(34,1 \%)$ sedangkan sedikit $(1,2 \%)$ yang memiliki gaya belajar multimodal yaitu visual, auditori, readwrite, kinestetik (VARK).

Gambaran gaya belajar mahasiswa di PSKG UMY ini hampir sama dengan hasil penelitian di UIN Syarif Hidayatullah Jakarta tahun 2014 tentang gambaran gaya belajar mahasiswa keperawatan angkatan 2009-2013 dengan gambaran hasil unimodal sebesar $89,4 \%$ dan multimodal sebesar $10,6 \%$ serta yang mendominasi adalah gaya kinestetik $(27,4 \%){ }^{16}$ Gaya belajar kinestetik dapat terbentuk karena metode pembelajaran yang lebih banyak 
menggunakan praktik keterampilan. Gaya kinestetik mengacu pada persepsi berdasarkan pengalaman dan praktik. Hal tersebut didapat melalui pengalaman pribadi dari contoh nyata, praktik atau simulasi, demonstrasi, dan melihat video atau film tentang hal-hal yang nyata. $^{7}$ Individu yang memiliki gaya belajar kinestetik memiliki kecenderungan perilaku berbicara perlahan, berorientasi pada fisik dan aktif bergerak, belajar memanipulasi dan praktik, sering menggunakan isyarat tubuh. ${ }^{13}$

Pengendalian faktor internal lain seperti keadaan jasmani, psikologis dan kelelahan subjek penelitian sedangkan faktor eksternal diantaranya keluarga, lingkungan belajar dan masyarakat diperlukan dalam penelitian lebih lanjut tentang hubungan antara kesiapan belajar SDLR dan gaya belajar (Learning Style) dengan hasil belajar.

\section{KESIMPULAN}

Hasil penelitian menunjukkan bahwa SDLR dan gaya belajar tidak berhubungan dengan tingkat kelulusan ujian MCQ Blok tahun pertama pada mahasiswa PSKG FKIK UMY.

\section{DAFTAR PUSTAKA}

1. Darmiany. Self-regulated learning mahasiswa pendidikan guru sekolah dasar (PGSD) tahun pertama. J Psikol Pendidik konseling. 2016;2(1):72-83.

2. Faroouqe I, Mustafa S, Mohammad F. Learning style preferences of first year undergraduate Medical Students. J Evid Based Med Healthc. 2014;1(11):1445-52.

3. Deyo ZM, Huynh D, Rochester D, Strupe DA, Kiser K. Readiness for self-directed learning and academic performance in abilities laboratory course. Am J Pharm Educ. 2011;75(2):1-6.
4. Slameto. Belajar dan faktor-faktor yang mempengaruhi. Jakarta: PT Rineka Cipta; 2013.

5. Nyambe H, Harsono, Rahayu GR. Faktor-faktor yang mempengaruhi self-directed learning readiness pada mahasiswa tahun pertama, kedua dan ketiga di Fakultas Kedokteran Universitas Hasanuddin dalam PBL. J Pendidik Kedokt Indones. 2016;5(2):67-77.

6. Utami PS, Gafur A. Pengaruh metode pembelajaran dan gaya belajar siswa terhadap hasil belajar IPS di SMP Negeri di Kota Yogyakarta. Harmon Sos J Pendidik IPS. 2015;2(1):97-103.

7. Fleming ND, Mills C. Not Another Inventory, Rather a Catalyst for Reflection. To Improv Acad. 1992;11:137-55.

8. Amin Z, Eng KH. Basics in Medical Education. Singapore: World Scientific Publishing Co.Pte.Ltd; 2003.

9. Dahlan MS. Statistik untuk Kedokteran dan Kesehatan. Ciracas: Salemba Medika; 2010.

10. Fisher $M$, King $J$, Tague $G$. Development of a self-directed learning readiness scale for Nursing Education. Nurse Educ Today. 2001;21(7):516-25.

11. Effendi. Hubungan readiness (kesiapan) belajar siswa dengan hasil belajar Fisika siswa kelas x SMK Muhammadiyah 03 Sukaraja. J Pendidik Fis. 2017;5(1):15-24.

12. Fitria S. Hubungan self-directed learning readiness dengan kelulusan ujian tulis blok semester pertama pada mahasiswa Fakultas Kedokteran Universitas Andalas Angkatan 2017. Universitas Andalas; 2018.

13. DePorter B, Hernacki. Quantum Learning: membiasakan belajar dan menyenangkan. Bandung: Kaifa; 2001. 
14. Dimyati, Mudjiono. Belajar dan pembelajaran. Jakarta: PT Rineka Cipta; 2006.

15. Purwoko S. Pengaruh penggunaan peta pikiran dan gaya belajar terhadap hasil belajar Geografi siswa SMP. J Pendidik Hum. 2014;2(2):191-5.
16. Utami PG. Gambaran gaya belajar mahasiswa Keperawatan 2009-2013 UIN Syarif Hidayatullah Jakarta tahun 2014. UIN Syarif Hidayatullah Jakarta; 2014. 